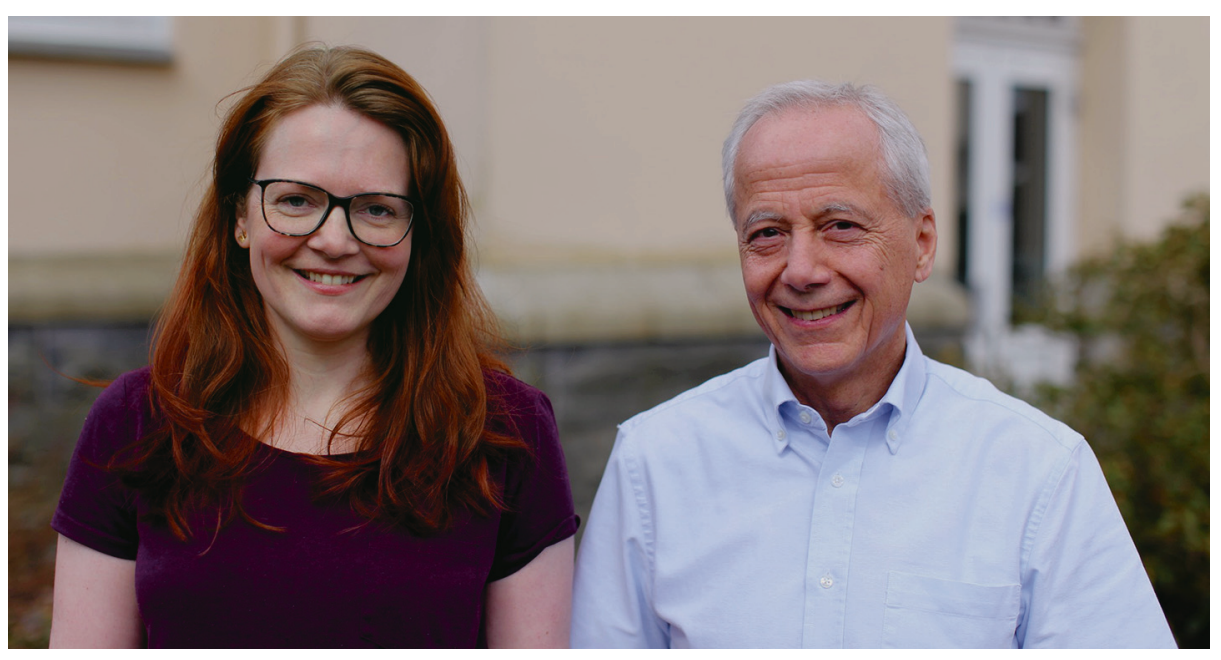

Janniche Torsvik og Laurence A. Bindoff. Foto: Kristoffer Haugarvoll

\title{
Defekte mitokondrier og Alzheimers demens
}

En defekt i et mitokondrielt protein fører til nevrodegenerasjon og bekrefter derved en forbindelse mellom mitokondrier og Alzheimers demens.

Det har lenge vært diskutert om det er en sammenheng mellom mitokondrieskade og nevrodegenerative sykdommer, men denne forbindelsen har vært vanskelig å bevise. En norsk studie, publisert i tidsskriftet EMBO Molecular Medicine, viser at en defekt i et mitokondrielt protein fører til både nevrodegenerasjon og opphopning av $\beta$-amyloid (1).

I en norsk familie med kognitive, psykiatriske plager og balanse- og koordinasjonsproblemer ble det påvist en mutasjon i genet som koder for pitrilysin metallopeptidase 1

(PITRM1). Dette enzymet bryter ned signalpeptidene som er nødvendig for dirigering av proteiner til mitokondriene. Enzymet er også involvert i nedbryting av $\beta$-amyloid-pro-

teinet. Undersøkelser av celler hos et av disse familiemedlemmene viste at genfeilen fører til redusert mengde av dette enzymet sammenlignet med friske kontrollceller. I spinalvæsken var konsentrasjonen av $\beta$-amyloidproteinet forhøyet, noe som indikerer redusert nedbrytning. I mus med lavt nivå av PITRM1-enzymet ble det påvist tegn på nevrodegenerasjon med $\beta$-amyloide avleiringer $i$ hjernen, og musene hadde motoriske problemer. Disse funnene viser at PITRM1enzymet er nødvending for at cellene skal kunne fjerne $\beta$-amyloid-proteinet og hindre avleiringene som til slutt fører til nevrodegenerasjon.

- Dette er første gangen det er vist at en mitokondriedefekt fører til $\beta$-amyloidavleiringer, sier Laurence Bindoff ved Haukeland universitetssykehus. - Hvordan $\beta$-amyloid tas opp i mitokondriene er fortsatt ikke kjent, heller ikke hvor viktig PITRM1-proteinet er for $\beta$-amyloidnedbryting totalt sett. Det blir viktig å finne flere pasienter med samme genfeil slik at $\beta$-amyloide avleiringer kan undersøkes klinisk både pre- og postmortem. Det gjenstår mye forskning for å forstå sammenhengen mellom mutasjoner i PITRM1genet og nevrologisk sykdom, men denne studien viser at det er en forbindelse mellom mitokondrier og avleiringspreget nevrodegenerasjon, sier han.

\section{Gruppe for mitokondrieforskning}

Forfatterne av denne artikkelen kommer hovedsakelig fra mitokondrieforskningsgruppen ved Haukeland universitetssykehus, som ledes av Laurence Bindoff. Janniche Torsvik er en av førsteforfatterne og postdoktor i gruppen. Studien ble gjennomført ved Nevrologisk avdeling, Haukeland universitetssykehus i samarbeid med Senter for medisinsk genetikk og molekylærmedisin ved Universitetet i Bergen og MRC Mitochondrial Biology Unit i Cambridge, Storbritannia. Mitokondriegruppen i Bergen forsker på forskjellige typer mitokondriesykdommer og bruker både kliniske og laboratoriebasert teknikker, bl.a. stamcellebasert forskning.

\section{Kaveh Rashidi}

Tidsskriftet

\section{Litteratur}

1. Brunetti D, Torsvik J, Dallabona C et al. Defective mitochondrial PITRM1 causes progressive neurodegeneration associated with APP and A $\beta$ accumulation. EMBO Mol Med 2015; e-publisert 23.12.2015.
Ordforklaringer

Nevrodegenerasjon: Tap av celler i sentralnervesystemet eller perifere nerveceller. Tapet kan omfatte hele nevronet, aksonet eller synapsen.

$\beta$-amyloid: Hovedkomponenten i amyloide plakk. Peptider med 36-43 aminosyrer.

Signalpeptid: En rekke av aminosyrer i et protein som er av betydning for at proteinet skal transporteres til riktig bestemmelsessted.

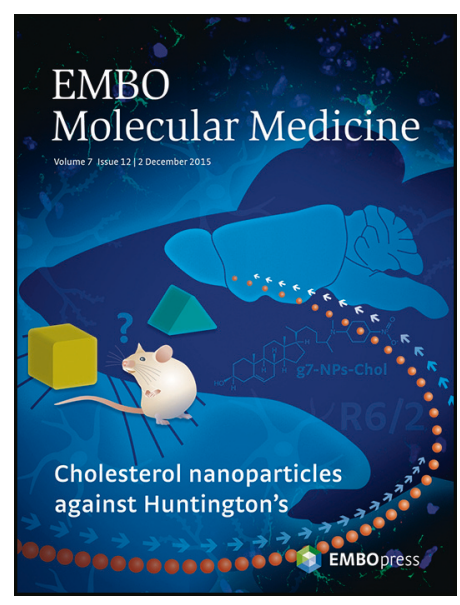

Artikkelen ble publisert i tidsskriftet EMBO Molecular Medicine i desember 2015 